\title{
Quality and Yield of Table Grapes cv. "Early Sweet" as Affected by Humic Acid and Nano Calcium Carbonate
}

\author{
Since 1996 \\ Hameed $^{2}$ and A.I. A. Ebead ${ }^{3}$ \\ Aly, M. A. M. ${ }^{1}$, M. M. Harhash ${ }^{1}$, T. M. Ezz ${ }^{1}$, A. A. Abdel \\ ${ }^{1}$ Plant Production Dept. Faculty of Agriculture (Saba Basha) Alexandria University \\ 2. Plant Production Dept., Desert Research Center, Egypt \\ ${ }^{3 .}$ Postgraduate student
}

ABSTRACT: This investigation was conducted in a private farm located at Khatatba, Monofaia Governorate, Egypt during two successive seasons (2018 and 2019) to study the effect of humic acid and nano calcium carbonate treatments on quality and yield of "Early sweet" table grapes using factorial randomized complete block design with three replicates for each treatment. Humic acid was added as a soil application at rats of control, $2.5,5$ and $7.5 \mathrm{~g} /$ tree, while, nano calcium carbonate $(0.5 \%)$ applied as a foliar application (control, once; two weeks after fruit setting and twice; two and four weeks after fruit setting).

Results showed that humic acid (at $7.5 \mathrm{~g} /$ tree) and nano calcium carbonate foliar application (two times at two and four weeks after fruit setting) recorded the best values of cluster weight, number of clusters/tree, yield/tree, physical characters, i.e. cluster length, cluster width, juice of 100 berry and fruit firmness, and chemical composition, i.e. TSS, TSS/acidity, vitamin C content and carbohydrates percentage as compared with the control treatment which recorded the minimum values of these characters during both seasons.

Keywords: Early sweet table grapes, humic acid, nano calcium carbonate, yield, fruit quality, chemical composition.

INTRODUCTION: Grapes (Vitis vinifera L.) rank is the top fruit crop over the world and the second crop after citrus in Egypt. Vineyard has continuously increased especially in the new reclaimed land. Since the total area of grape in Egypt reached about 192934 feddans producing about 1686706 tons according to the Statistics of the Ministry of Agriculture (2017). Grapevines cultivation area in Egypt has progressively developed in recent years. The great of this area is concentrated in the new reclaimed soils where grapes have recently become a key component of Egyptian horticultural exports (Ali et al., 2013).

Early sweet grapevine cultivar is considered a prime and outstanding grapevine cultivar grown under Egypt conditions. It ripens early especially when treated with breakages and easily marketing to most foreign countries. Early sweet grape is a large seedless berry with a creamy white color. The high sugar level gives this grape a sweet flavor with a hint of Muscat and an extremely high juice level (Ali and Mohamed 2016).

Fertilizers are important factors in agriculture since they provide essential nutrients for plant growth and development (Moraru et al., 2003). The beneficial effects of humic substances for enhancing plant growth have been well-known since the 1980s, and they can be supportive to a circular economy (Agrawal and Rathore, 2014; Naderi et al., 2011; Jindo et al., 2020).
Humic acid significantly increased qualitative and quantitative parameters of table grape (Ferrara and Brunetti, 2010). Humic substances enhanced aerial part and root system of papaya seedling (Cavalcante et al., 2011). Also, quantitative and qualitative characteristics of strawberry were improved by foliar application of humic acid at 1.5-3 $\mathrm{mg} \mathrm{l}^{-1}$ (Farahi et al., 2013). Humic acid application significantly improved tree size, growth, yield, fruit quality and leaf nutrient contents of Egyptian lime trees (Ennab, 2016).

Nano fertilizers are aimed to make nutrients more available, consequently increasing nutrient use efficiency (Suppan, 2013). Some characteristics of nanoparticles, including the large specific surface area, unique magnetic/optical properties, electronic states, and catalytic reactivity confer nanoparticles a better reactivity than the equivalent bulk materials (Agrawal and Rathore, 2014).

Nano calcium carbonate $(0.5 \mathrm{~g} / \mathrm{l})$ treatment alleviated the common negative effects on different plant growth parameters of tomato plants hybrid Super strain B irrigated with saline water compared to all other treatments. Also, fruit yield and nutritional status were significantly improved by nano calcium treatments (Tantawy et al., 2014). Zaghloul date palms initial fruit of setting $\%$, fruit retention $\%$, bunch weight, yield/palm and fruit quality parameters were enhanced by three times of $\mathrm{Zn}, \mathrm{Fe}$ and $\mathrm{Mn}$ in

Journal Article (C) 2021 by (JAAR) is licensed under CC BY-NC 4.0 CC) 
chelated form at 25 to $100 \mathrm{ppm}$ or via nano form at 2.5 to $20 \mathrm{ppm}$ over the control treatment (ElSayed et al., 2017).

Therefore, the main objective of this study was to investigate the effect of different levels of humic acid and nano calcium carbonate on quality and yield of "Early Sweet" table grapes.

\section{MATERIALS AND METHODS}

This investigation was conducted in a private farm located at Khatatba, Monofaia Governorate, Egypt on 6-year-old "Early sweet" table grapevines during two successive seasons (2018 and 2019). Physical and chemical properties of the experimental soil are shown in Table (1). The trees were spaced at $2 \times 3 \mathrm{~m}$ apart and irrigated by drip irrigation system and received similar cultural practices.

Table (1): The initial physical and chemical properties of the experimental soil in 2018 season.

\begin{tabular}{|c|c|c|}
\hline Parameter & Value & Unit \\
\hline \multicolumn{3}{|l|}{ Mechanical Analysis } \\
\hline Sand & 85.52 & $\%$ \\
\hline Silt & - & $\%$ \\
\hline Clay & 14.48 & $\%$ \\
\hline Textural class & \multicolumn{2}{|c|}{ Loamy sand } \\
\hline $\mathrm{pH}(1: 1)$ & 7.2 & - \\
\hline $\mathrm{Ca} \mathrm{Co}_{3}$ & 2.7 & $\%$ \\
\hline $\mathrm{EC}(1: 1$, water extract $)$ & 0.56 & $\mathrm{dS} / \mathrm{m}$ \\
\hline O.M & 5.2 & $\%$ \\
\hline \multicolumn{3}{|l|}{ Soluble cations } \\
\hline $\mathrm{Ca}^{2+}$ & 5.2 & $\mathrm{meq} / 1$ \\
\hline $\mathrm{Mg}^{2+}$ & 2.2 & $\mathrm{meq} / 1$ \\
\hline $\mathrm{Na}^{+}$ & 13.7 & $\mathrm{meq} / \mathrm{l}$ \\
\hline $\mathrm{K}^{+}$ & 0.7 & $\mathrm{meq} / 1$ \\
\hline \multicolumn{3}{|l|}{ Soluble anions } \\
\hline $\mathrm{HCO}^{-}$ & 8.2 & $\mathrm{meq} / 1$ \\
\hline $\mathrm{Cl}^{-}$ & 11.2 & $\mathrm{meq} / \mathrm{l}$ \\
\hline $\mathrm{SO}_{4}^{2-}$ & 17 & $\mathrm{meq} / \mathrm{l}$ \\
\hline \multicolumn{3}{|l|}{ Available nutrients } \\
\hline Nitrogen $(\mathrm{N})$ & 14 & $\mathrm{mg} / \mathrm{l}$ \\
\hline Phosphorus (P) & 15 & $\mathrm{mg} / \mathrm{kg}$ \\
\hline Potassium $(\mathrm{K})$ & 12.35 & $\mathrm{mg} / \mathrm{kg}$ \\
\hline
\end{tabular}

\section{Experimental Design}

The experiment was arranged in a factorial randomized complete block design on 72 trees as 12 treatments were represented with three replicates and each replicate included two trees.

Humic acid treatments included control, 2.5, 7.5 and $5 \mathrm{~g} /$ tree as a soil application. Nano calcium carbonate (foliar application $0.5 \%$ ) treatments were control, once (two weeks after fruit setting) and twice (two and four weeks after fruit setting).

\section{Data recorded}

\section{A) Yield (kg/vine)}

At harvesting date when TSS \% of berries reached about 16-17 \% in control, average yield/vine, $(\mathrm{kg})$ and cluster weight $(\mathrm{g})$.

\section{B) Physical properties}

Hundred berries/cluster were used to determine the average of berry length ( $\mathrm{mm})$, berry diameter $(\mathrm{mm})$, juice volume of 100 berries (cm3) and berry firmness (lb/inch2) by using a texture analyzer instrument; fruit hardness tester, no 510-as.
A sample of 5 clusters/vine was taken for determining cluster length $(\mathrm{cm})$, cluster width (cm) and number of berries/cluster.

\section{C) Chemical fruit characteristics}

Total soluble solids (TSS \%) was measured by using hand refractometer (ATAGrO Co. LTD, Tokya, Japan). Total acidity (\%) was determined by direct titrating of $0.1 \mathrm{~N}$ sodium hydroxide using phenolphthalein $1 \%$ as an indicator and expressed as citric acid percentage according to the AOAC (1985). TSS/acid ratio was calculated by dividing the values of TSS with the corresponding values of titratable acidity. Vitamin $\mathrm{C}$ was determined by titration with 2, 6 dichloro phenol-indo-phenol (AOAC, 1985) and calculated as $\mathrm{mg} / 100 \mathrm{ml}$ juice. Total carbohydrates (\%) were determined according to Mahadevan and Sridhar (1986)

\section{Statistical analysis:}

Results of the measured parameters were subjected to computerized statistical analysis using MSTAT package for analysis of variance 
(ANOVA) and means of treatments were compared using LSD at 0.05 according to Snedecor and Cochran (1990).

\section{RESULTS AND DISCUSSION}

\section{A) Yield}

Results presented in Table (2) revealed the effect of humic acid application on average cluster weight, number of clusters/vine and yield/vine $(\mathrm{kg})$ of table grapes cv. "Early sweet". The results showed that the highest values of cluster weight (455.67 and $510.35 \mathrm{~g}$ ), number of clusters/vine (36.77 and 40.85) and yield/vine (16.73 and $20.81 \mathrm{~kg}$ ) were recorded with humic acid at $7.5 \mathrm{~g} / \mathrm{vine}$, while control treatment recorded the lowest values of cluster weight (347.70 and $389.42 \mathrm{~g}$ ), number of clusters/vine
(24.27 and 38.74) and yield/vine (12.11 and $15.07 \mathrm{~kg}$ ) during both seasons.

Results in the same table indicated that foliar application of nano calcium carbonate twice (two and four weeks after fruit setting) recorded the highest mean values of cluster weight (447.53 and $501.24 \mathrm{~g})$, number of clusters/vine (34.79 and $38.65)$, and yield/vine (15.60 and $19.41 \mathrm{~kg}$ ), while control treatment recorded the lowest values of cluster weight $(362.50$ and $406.00 \mathrm{~g})$, number of clusters/vine (36.15 and 40.16) and yield/vine (13.14 and $16.35 \mathrm{~kg}$ ) during both seasons.

The interaction between humic acid and nano calcium carbonate was significant on cluster weight, yield/vine and number of clusters/vine in most cases.

Table (2): Effect of humic acid and nano calcium carbonate on cluster weight, number of clusters/vine and yield/vine of "Early sweet" table grapes during 2018 and 2019 seasons.

\begin{tabular}{|c|c|c|c|c|c|c|c|}
\hline \multirow{2}{*}{\multicolumn{2}{|c|}{ Treatments }} & \multicolumn{2}{|c|}{ Cluster weight (g) } & \multicolumn{2}{|c|}{$\begin{array}{l}\text { No. of clusters/ } \\
\text { vine }\end{array}$} & \multicolumn{2}{|c|}{$\begin{array}{l}\text { Yield/vine } \\
\text { (kg) }\end{array}$} \\
\hline & & 2018 & 2019 & 2018 & 2019 & 2018 & 2019 \\
\hline \multicolumn{8}{|c|}{ A) Humic acid (HA) } \\
\hline Control & & $347.70 d$ & $389.42 d$ & $34.27 \mathrm{~d}$ & $38.74 \mathrm{c}$ & $12.11 \mathrm{~d}$ & $15.07 \mathrm{~d}$ \\
\hline $2.5 \mathrm{~g}$ & & $395.82 \mathrm{c}$ & $443.32 c$ & $34.86 \mathrm{c}$ & $38.08 \mathrm{~d}$ & $13.55 \mathrm{c}$ & $16.86 \mathrm{c}$ \\
\hline $5 \mathrm{~g}$ & & $417.9 \mathrm{~b}$ & $468.05 b$ & $36.08 b$ & $40.09 \mathrm{~b}$ & $15.05 \mathrm{~b}$ & $18.73 b$ \\
\hline $7 . \overrightarrow{5} \mathrm{~g}$ & & $455.67 \mathrm{a}$ & $510.35 \mathrm{a}$ & $36.77 \mathrm{a}$ & $40.85 a$ & $16.73 a$ & $20.81 \mathrm{a}$ \\
\hline $\operatorname{LSD}_{(0.05)}$ & & 3.85 & 4.31 & 0.32 & 0.36 & 0.02 & 0.03 \\
\hline \multicolumn{8}{|c|}{ B) $\mathrm{Nano} \mathrm{CaCO}_{3}$} \\
\hline Control & & $362.50 \mathrm{c}$ & $406.00 \mathrm{c}$ & $34.79 \mathrm{c}$ & $38.65 \mathrm{c}$ & $13.14 \mathrm{c}$ & $16.35 \mathrm{c}$ \\
\hline Once & & $402.78 b$ & $451.12 b$ & $35.56 \mathrm{~b}$ & $39.51 b$ & $14.35 b$ & $17.85 \mathrm{~b}$ \\
\hline Twice & & $447.53 \mathrm{a}$ & $501.24 \mathrm{a}$ & $36.15 \mathrm{a}$ & $40.16 \mathrm{a}$ & $15.60 \mathrm{a}$ & $19.41 \mathrm{a}$ \\
\hline $\mathbf{L S D}_{(0.05)}$ & & 3.33 & 3.73 & 0.28 & 0.31 & 0.02 & 0.02 \\
\hline Interaction ( & & $* *$ & $* *$ & ns & ns & $* *$ & $* *$ \\
\hline \multirow[t]{2}{*}{ HA } & $\mathrm{Nano} \mathrm{CaCO}_{3}$ & & & & & & \\
\hline & Control & 311.77 & 349.18 & 35.11 & 39.02 & 10.95 & 13.62 \\
\hline \multirow[t]{3}{*}{ Control } & Once & 346.41 & 387.98 & 35.12 & 39.02 & 12.16 & 15.14 \\
\hline & Twice & 384.90 & 431.09 & 34.36 & 38.17 & 13.23 & 16.46 \\
\hline & Control & 354.92 & 397.51 & 35.03 & 38.92 & 12.43 & 15.47 \\
\hline \multirow[t]{3}{*}{$2.5 \mathrm{~g}$} & Once & 394.36 & 441.68 & 34.27 & 38.08 & 13.52 & 16.82 \\
\hline & Twice & 438.18 & 490.76 & 33.53 & 37.25 & 14.69 & 18.28 \\
\hline & Control & 374.72 & 419.69 & 36.87 & 40.96 & 13.81 & 17.19 \\
\hline \multirow[t]{3}{*}{$5 \mathrm{~g}$} & Once & 416.36 & 466.32 & 36.07 & 40.08 & 15.02 & 18.69 \\
\hline & Twice & 462.62 & 518.14 & 35.29 & 39.21 & 16.33 & 20.32 \\
\hline & Control & 408.59 & 457.62 & 37.58 & 41.75 & 15.35 & 19.10 \\
\hline \multirow[t]{2}{*}{$7.5 \mathrm{~g}$} & Once & 453.99 & 508.47 & 36.77 & 40.85 & 16.69 & 20.76 \\
\hline & Twice & 504.43 & 564.97 & 35.97 & 39.96 & 18.14 & 22.57 \\
\hline \multicolumn{2}{|c|}{$\mathbf{L S D}_{(0.05)}$} & 3.85 & 4.31 & 0.32 & 0.36 & 0.02 & 0.03 \\
\hline
\end{tabular}

\section{B) Physical characteristics:}

It is evident from the obtained results in Table (3) that, increasing humic acid concentrations increased cluster length, cluster width, number of berries/cluster, juice volume/100 berries and fruit firmness of "Early sweet" table grapes. The results revealed that humic acid application up to
$7.5 \mathrm{~g} / \mathrm{vine}$ recorded the highest mean values of cluster length $(25.27$ and $28.30 \mathrm{~cm})$, cluster width (18.63 and $20.86 \mathrm{~cm}$ ), number of berries/cluster (112.60 and 126.11), juice volume/100 berries (144.92 and $162.31 \mathrm{~cm} 3)$, and fruit firmness (13.77 and $15.42 \mathrm{Lb} / \mathrm{inch} 2$ ) as compared with 
control treatments which recorded the lowest values in this respect during both seasons.

In addition, foliar application of nano calcium carbonate twice (two and four weeks after fruit setting) recorded the highest mean values of cluster length $(23.56$ and $26.38 \mathrm{~cm})$, cluster width (17.37 and $19.45 \mathrm{~cm})$, number of berries/cluster (104.98 and 117.57), juice volume/100 berries (135.11 and $151.33 \mathrm{~cm} 3)$ and fruit firmness (12.87 and 14.41 Lb/inch2) as compared with control treatment which recorded the lowest significant values during 2018 and 2019 seasons.

The interaction between humic acid and nano calcium carbonate gave the highest values of cluster length, cluster width, number of berries/cluster, juice volume/100 berries and fruit firmness by humic acid at $7.5 \mathrm{~g}$ with foliar application of nano calcium carbonate (twice) during both seasons

Table (3): Effect of humic acid and nano calcium carbonate on cluster length, width and no. of berries/cluster of "Early sweet" table grapes during 2018 and 2019 seasons.

\begin{tabular}{|c|c|c|c|c|c|c|c|c|c|c|c|}
\hline \multirow{2}{*}{\multicolumn{2}{|c|}{ Treatments }} & \multicolumn{2}{|c|}{$\begin{array}{l}\text { Cluster length } \\
\text { (cm) }\end{array}$} & \multicolumn{2}{|c|}{$\begin{array}{l}\text { Cluster width } \\
\text { (cm) }\end{array}$} & \multicolumn{2}{|c|}{$\begin{array}{c}\text { No. of } \\
\text { berries/cluster }\end{array}$} & \multicolumn{2}{|c|}{$\begin{array}{l}\text { Juice volume } / 100 \\
\text { berries }\left(\mathrm{cm}^{3}\right)\end{array}$} & \multicolumn{2}{|c|}{$\begin{array}{l}\text { Fruit firmness } \\
\left(\text { Lb/inch }^{2}\right)\end{array}$} \\
\hline & & 2018 & 2019 & 2018 & 2019 & 2018 & 2019 & 2018 & 2019 & 2018 & 2019 \\
\hline \multicolumn{12}{|c|}{ A) Humic acid (HA) } \\
\hline \multicolumn{2}{|c|}{ Control } & $18.42 \mathrm{~d}$ & $20.63 d$ & $13.52 \mathrm{~d}$ & $15.14 d$ & $82.08 \mathrm{~d}$ & $91.93 \mathrm{~d}$ & $105.65 d$ & $118.32 d$ & $10.20 \mathrm{~d}$ & $11.43 \mathrm{~d}$ \\
\hline \multicolumn{2}{|c|}{$2.5 \mathrm{~g}$} & $20.46 c$ & $22.92 \mathrm{c}$ & $15.08 \mathrm{c}$ & $16.89 \mathrm{c}$ & $91.20 \mathrm{c}$ & $102.15 \mathrm{c}$ & $117.38 \mathrm{c}$ & $131.47 \mathrm{c}$ & $11.18 \mathrm{c}$ & $12.52 \mathrm{c}$ \\
\hline \multicolumn{2}{|c|}{$5 \mathrm{~g}$} & $22.74 b$ & $25.47 b$ & $16.76 \mathrm{~b}$ & $18.78 b$ & $101.33 b$ & $113.49 \mathrm{~b}$ & $130.42 b$ & $146.07 \mathrm{~b}$ & $12.42 b$ & $13.91 b$ \\
\hline \multicolumn{2}{|c|}{$7.5 \mathrm{~g}$} & $25.27 \mathrm{a}$ & $28.30 \mathrm{a}$ & $18.63 \mathrm{a}$ & $20.86 a$ & $112.60 \mathrm{a}$ & $126.11 \mathrm{a}$ & $144.92 \mathrm{a}$ & $162.31 \mathrm{a}$ & $13.77 \mathrm{a}$ & $15.42 \mathrm{a}$ \\
\hline \multicolumn{2}{|l|}{$\operatorname{LSD}_{(0.05)}$} & 0.07 & 0.07 & 0.07 & 0.08 & 0.11 & 0.13 & 0.38 & 0.43 & 0.04 & 0.4 \\
\hline \multicolumn{12}{|c|}{ B) $\underline{\operatorname{Nano} \mathrm{CaCO}_{3}}$} \\
\hline \multicolumn{2}{|c|}{ Control } & $19.94 \mathrm{c}$ & $22.33 c$ & $14.65 \mathrm{c}$ & $16.41 \mathrm{c}$ & $88.85 \mathrm{c}$ & $99.52 \mathrm{c}$ & $114.36 \mathrm{c}$ & $128.08 \mathrm{c}$ & $10.99 \mathrm{c}$ & $12.31 \mathrm{c}$ \\
\hline \multicolumn{2}{|c|}{ Once } & $21.67 b$ & $24.27 b$ & $15.98 \mathrm{~b}$ & $17.89 b$ & $96.58 b$ & $108.17 b$ & $124.30 \mathrm{~b}$ & $139.22 b$ & $11.83 b$ & $13.24 b$ \\
\hline \multicolumn{2}{|c|}{ Twice } & $23.56 \mathrm{a}$ & $26.38 \mathrm{a}$ & $17.37 \mathrm{a}$ & $19.45 \mathrm{a}$ & $104.98 \mathrm{a}$ & $117.57 \mathrm{a}$ & $135.11 \mathrm{a}$ & $151.33 \mathrm{a}$ & $12.87 \mathrm{a}$ & $14.41 \mathrm{a}$ \\
\hline \multicolumn{2}{|c|}{$\mathbf{L S D}_{(0.05)}$} & 0.06 & 0.06 & 0.06 & 0.07 & 0.10 & 0.11 & 0.33 & 0.37 & 0.03 & 0.04 \\
\hline \multicolumn{2}{|c|}{ Interaction (AXB) } & $* *$ & $* *$ & $* *$ & $* *$ & $* *$ & $* *$ & $* *$ & $* *$ & $* *$ & $* *$ \\
\hline & $\begin{array}{c}\text { Nano } \\
\mathrm{CaCO}_{3}\end{array}$ & & & & & & & & & & \\
\hline & Control & 16.91 & 18.93 & 12.28 & 13.75 & 75.34 & 84.38 & 96.97 & 108.61 & 9.66 & 10.82 \\
\hline \multirow[t]{3}{*}{ Control } & Once & 18.38 & 20.58 & 13.55 & 15.17 & 81.89 & 91.72 & 105.40 & 118.05 & 10.04 & 11.24 \\
\hline & Twice & 19.97 & 22.37 & 14.72 & 16.49 & 89.01 & 99.69 & 114.57 & 128.31 & 10.91 & 12.22 \\
\hline & Control & 18.78 & 21.03 & 13.84 & 15.51 & 83.71 & 93.76 & 107.74 & 120.67 & 10.26 & 11.49 \\
\hline \multirow[t]{3}{*}{$2.5 \mathrm{~g}$} & Once & 20.41 & 22.86 & 15.05 & 16.85 & 90.99 & 101.91 & 117.11 & 131.17 & 11.15 & 12.49 \\
\hline & Twice & 22.19 & 24.86 & 16.36 & 18.32 & 98.90 & 110.77 & 127.30 & 142.57 & 12.12 & 13.58 \\
\hline & Control & 20.87 & 23.37 & 15.39 & 17.32 & 93.01 & 104.17 & 119.71 & 134.07 & 11.40 & 12.77 \\
\hline \multirow[t]{3}{*}{$5 \mathrm{~g}$} & Once & 22.69 & 25.41 & 16.72 & 18.73 & 101.10 & 113.23 & 130.12 & 145.74 & 12.39 & 13.88 \\
\hline & Twice & 24.66 & 27.62 & 18.18 & 20.36 & 109.89 & 123.07 & 141.44 & 158.41 & 13.47 & 15.08 \\
\hline & Control & 23.19 & 25.97 & 17.10 & 19.15 & 103.35 & 115.75 & 133.02 & 148.98 & 12.62 & 14.14 \\
\hline \multirow[t]{2}{*}{$7.5 \mathrm{~g}$} & Once & 25.21 & 28.24 & 18.59 & 20.82 & 112.33 & 125.81 & 144.58 & 161.94 & 13.72 & 15.37 \\
\hline & Twice & 27.40 & 30.69 & 20.20 & 22.62 & 122.10 & 136.76 & 157.16 & 176.02 & 14.97 & 16.76 \\
\hline \multicolumn{2}{|l|}{$\operatorname{LSD}_{(0.05)}$} & 0.07 & 0.07 & 0.07 & 0.08 & 0.11 & 0.13 & 0.38 & 0.43 & 0.04 & 0.4 \\
\hline \multicolumn{6}{|c|}{$\begin{array}{l}\text { These results are in agreement with } \\
\text { those of Concheri et al., 1994; Nardi et al., } \\
\text { 1996; Chen } \text { et al., 2004; Ferrara and Brunetti, } \\
\mathbf{2 0 0 8} \text { who demonstrated that increases in total } \\
\text { yield were probably related to the effect of humic } \\
\text { acid fertilization as it helped in stimulating plant } \\
\text { growth and consequently yield by acting on } \\
\text { mechanisms involved in: cell respiration, } \\
\text { photosynthesis, protein synthesis, water and } \\
\text { nutrients uptake, increase of microbial } \\
\text { population, and enzyme activities. Also, foliar } \\
\text { application of humic acid causes a considerable } \\
\text { increase in berry size, weight and width and thus, }\end{array}$} & \multicolumn{6}{|c|}{$\begin{array}{l}\text { increased cluster weight compared with the } \\
\text { control treatment. This probably ascribes as the } \\
\text { functions of humic acid, which have the same } \\
\text { effects of some kinds of hormones such as auxin, } \\
\text { gibberellin and cytokinin which their activities } \\
\text { affect the volume and weight of berries. } \\
\text { C) Chemical fruit characteristics: } \\
\text { Results in Tables (4 and 5) indicated } \\
\text { that humic acid had a positive effect on TSS, } \\
\text { acidity percentage, TSS/acidity, vitamin C } \\
\text { content and carbohydrates percentage as } \\
\text { compared to control treatment during both } \\
\text { seasons. However, humic acid up to } 7.5 \text { g/vine } \\
\text { recorded the highest mean values of TSS (16.54 }\end{array}$} \\
\hline
\end{tabular}


and $18.53 \%)$, TSS/acidity (35.67 and 38.05), vitamin C (50.54 and $56.61 \mathrm{mg} / 100 \mathrm{ml}$ juice) and carbohydrates (29.51 and $33.05 \%$ ) as compared with control treatments which recorded the highest acidity (0.64 and $0.67 \%)$ but gave the lowest mean values of TSS, TSS/acidity, vitamin $\mathrm{C}$ content and carbohydrates percentage during both seasons.

Table (4): Effect of humic acid and nano calcium carbonate on TSS, acidity and TSS/acidity of "Early sweet" table grapes during 2018 and 2019 seasons.

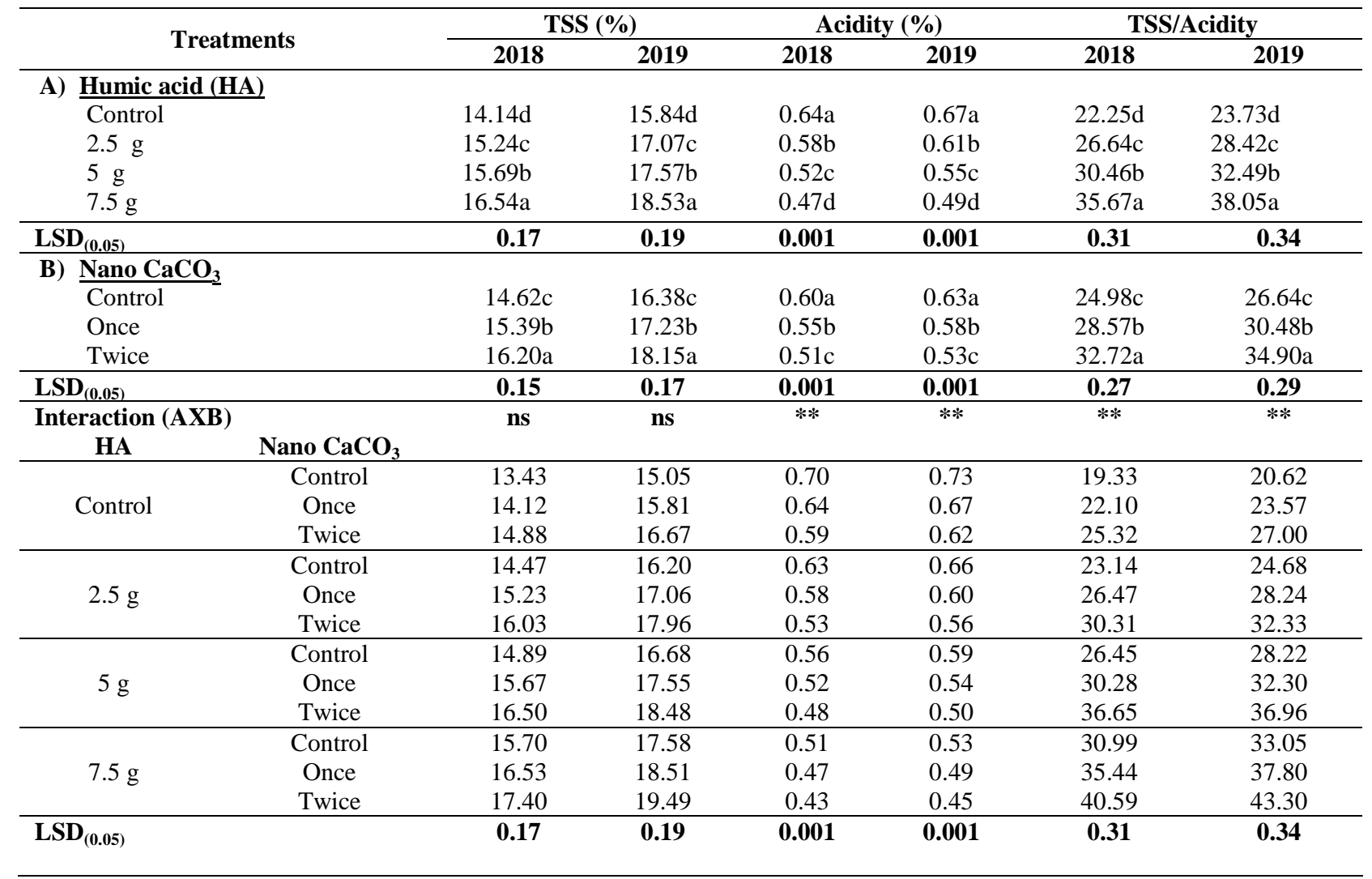


Table (5): Effect of humic acid and nano calcium carbonate on vitamin $\mathrm{C}(\mathrm{mg} / 100 \mathrm{ml}$ juice) and carbohydrates (\%) of "Early sweet" table grapes during 2018 and 2019 seasons.

\begin{tabular}{|c|c|c|c|c|c|}
\hline \multicolumn{2}{|c|}{ Treatments } & \multicolumn{2}{|c|}{$\begin{array}{c}\text { Vitamin C } \\
\text { (mg/100 ml juice) }\end{array}$} & \multicolumn{2}{|c|}{$\begin{array}{c}\text { Carbohydrates } \\
(\%)\end{array}$} \\
\hline \multirow{2}{*}{\multicolumn{6}{|c|}{ A) Humic acid (HA) }} \\
\hline & & & & & \\
\hline Control & & $36.84 d$ & $41.26 \mathrm{~d}$ & $21.21 \mathrm{~d}$ & $23.76 \mathrm{~d}$ \\
\hline $2.5 \mathrm{~g}$ & & $40.94 c$ & $45 . .85 c$ & $23.91 \mathrm{c}$ & $26.77 \mathrm{c}$ \\
\hline $5 \mathrm{~g}$ & & $45.49 \mathrm{~b}$ & $50.94 b$ & $26.34 b$ & $29.50 \mathrm{~b}$ \\
\hline $7.5 \mathrm{~g}$ & & $50.54 \mathrm{a}$ & $56.61 \mathrm{a}$ & $29.51 \mathrm{a}$ & $33.05 \mathrm{a}$ \\
\hline $\mathbf{L S D}_{(0.05)}$ & & 0.21 & 0.23 & 0.32 & 0.35 \\
\hline \multicolumn{6}{|c|}{ B) $\underline{\text { Nano } \mathrm{CaCO}_{3}}$} \\
\hline Control & & $39.88 c$ & $44.67 \mathrm{c}$ & $22.83 c$ & $25.57 \mathrm{c}$ \\
\hline Once & & $43.35 b$ & $48.55 b$ & $25.37 \mathrm{~b}$ & $28.41 b$ \\
\hline Twice & & $47.12 \mathrm{a}$ & $52.78 \mathrm{a}$ & $27.54 \mathrm{a}$ & $30.84 a$ \\
\hline $\mathbf{L S D}_{(0.05)}$ & & 0.18 & 0.20 & 0.27 & 0.31 \\
\hline Interaction $(A$ & & $* *$ & $* *$ & $* *$ & $* *$ \\
\hline \multirow[t]{2}{*}{ HA } & Nano $\mathrm{CaCO}_{3}$ & & & & \\
\hline & Control & 33.81 & 37.87 & 19.02 & 21.31 \\
\hline \multirow[t]{3}{*}{ Control } & Once & 36.76 & 41.17 & 21.13 & 23.67 \\
\hline & Twice & 39.95 & 44.75 & 23.49 & 26.30 \\
\hline & Control & 37.57 & 42.08 & 21.16 & 28.89 \\
\hline \multirow[t]{3}{*}{$2.5 \mathrm{~g}$} & Once & 40.84 & 45.75 & 24.01 & 29.23 \\
\hline & Twice & 44.40 & 49.72 & 26.10 & 24.20 \\
\hline & Control & 41.75 & 46.76 & 24.01 & 26.89 \\
\hline \multirow[t]{3}{*}{$5 \mathrm{~g}$} & Once & 45.38 & 50.82 & 26.68 & 29.87 \\
\hline & Twice & 49.33 & 55.25 & 28.33 & 31.73 \\
\hline & Control & 46.39 & 51.96 & 26.68 & 29.88 \\
\hline \multirow[t]{2}{*}{$7.5 \mathrm{~g}$} & Once & 50.43 & 56.48 & 29.64 & 33.20 \\
\hline & Twice & 54.81 & 61.39 & 32.22 & 36.08 \\
\hline $\operatorname{LSD}_{(0.05)}$ & & 0.21 & 0.23 & 0.32 & 0.35 \\
\hline
\end{tabular}

On the other side, foliar application of nano calcium carbonate twice (two and four weeks after fruit setting) recorded the highest mean values of TSS (16.20 and $18.15 \%)$, TSS/acidity (32.72 and 34.90), vitamin C (47.12 and $52.78 \mathrm{mg} / 100 \mathrm{ml}$ juice) and carbohydrates (27.54 and $30.84 \%$ ) as compared to control treatment which recorded the highest acidity percentage $(0.60$ and $0.63 \%)$, but it recorded the lowest mean values of TSS, TSS/acidity, vitamin $\mathrm{C}$ content and carbohydrates percentage during both seasons.

The interaction between humic acid and nano calcium carbonate was highly significant on acidity percentage, TSS/acidity, vitamin C content and carbohydrates percentage, while not significant on TSS percentage during both seasons.

These results are confirmed by the findings of Liu et al. (2005) who found higher soluble sugars and proteins of the aerial parts of the plants treated with calcium. As was observed in this study, Liu et al., (2005) observed an improvement in the absorption of nutritional elements in the contents in the shoots. The improvements in the contents of soluble sugars, proteins and nutritional elements may explain the high contents of the total soluble solids recorded in the tomato fruits (Tantawy et al., 2014). Also, EL Ghayaty et al. (2019) showed that humic acid treatment improved total soluble solids, total soluble solids/total acidity of grapevine varieties.

\section{CONCLUSION:}

It could be concluded that humic acid as a soil application at $7.5 \mathrm{~g} /$ tree and nano calcium carbonate as a foliar application two times (two and four weeks after fruit setting) maybe improve fruit quality and yield of "Early sweet" table grapes under study conditions.

\section{REFERENCES}

Agrawal, S. and P. Rathore (2014). Nanotechnology pros and cons to agriculture: A review. Intl. J. Curr. Microbiol. Appl. Sci., 3:43-55.

Ali, H. A. and M. A. Kh. Mohamed (2016). Effect of fruiting spur length and spraying seaweed extract on yield and berries quality of Early sweet grapevines. Assiut J. Agric. Sci., 47(6-2):504-517.

Ali, M.A., R.S.S. El-Gendy and O.A. Ahmed (2013). Minimizing adverse effects of salinity in vineyards. J. Hort. Sci. Ornament. Plants, 5 (1), 12-21.

AOAC (1985). Official Methods of Analysis pp 490-510. Association of Official Analytical ChemistsWashington, D. C.

Cavalcante, I.H.L., R.R.S. Da Silva, F.G. Albano, F.N. De Lima and A. De S. 
Marques (2011). Foliar spray of humic substances on seedling production of papaya (Pawpaw). J. Agron., 10(4): 118-122.

Chen, Y., M. De Nobili and T. Aviad (2004). Stimulatory effect of humic substances on plant growth. In soil organic matter in sustainable agriculture. (Eds Magdoff F, Weil RR). Boca Raton, FL: CRC Press, pp: 103-129.

Concheri, G., S. Nardi, A. Piccolo, N. Rascio and G. Dell'Agnola, 1994. Effects of humic fractions on morphological changes related to invertase and peroxidase activities in wheat seedlings. Humic substances in the global environment and implications on human health (Senesi N., Miano TM, eds). Elsevier Sci, Amsterdam, The Netherlands, 257-262.

EL Ghayaty, S. H., G. A. Abdrabboh, A. E. Hamdy and A. F. Ahmed (2019). Effect of soil applications antisalinity agent on growth, yield and fruit quality of Superior seedless grapevines (Vitis vinifera L.). AlAzhar J. Agric. Res., 44 (2): 24-34

El-Sayed, M. A., M. M. El-Wasfy and O. G. A. Abdalla (2017). Effect of spraying some micronutrients via normal versus nanotechnology on fruiting of Zaghloul date palms. New York Sci. J., 10(12):1-10

Ennab, H.A. (2016). Effect of humic acid on growth and productivity of Egyptian lime trees (Citrus aurantifolia Swingle) under salt stress conditions. J. Agric. Res. Kafr El-Sheikh Univ., 42(4): 494-505

Farahi, M. H., A. Aboutalebi, S. Eshghi, M. Dastyaran and F. Yosefi (2013). Foliar application of humic acid on quantitative and qualitative characteristics of 'Aromas' strawberry in soilless culture. Agric. Communications, 1(1): 13-16.

Ferrara, G. and G. Brunetti (2008). Influence of foliar applications of humic acids on yield and fruit quality of table grape cv. Italia. J. Int. Sci. Vigne Vin, 42(2): 79-87

Ferrara, G. and G. Brunetti (2010). Effects of the times of application of a soil humic acid on berry quality of table grape (Vitis vinifera L.) cv. Italia. Spanish J. Agric. Res., 8(3): 817822.
Jindo, K., F. L. Olivares, D. J. P. Malcher, M. A. Sánchez-Monedero, C. Kempenaar and L. P. Canellas (2020). From Lab to Field: Role of humic substances under open-field and greenhouse conditions as biostimulant and biocontrol agent. Front. Plant Sci., 11:426.

Liu, X., F. Zhang, S. Zhang, X. He, R. Wang, $Z$. Feng and $Y$. Wang (2005). Responses of peanut to nano calcium carbonate. Plant Nutri. \& Fertili. Sci., 11(3): 385-389.

Mahadevan, A. and R. Sridhar (1986). Methods in Physiological Plant Pathology. $3^{\text {rd }}$ Edn. Sivakami Publication, Madras. India p. 316.

Moraru, C. I., P. P. Chithra, Q. Huang, T. Paul, S. Liu and K. L.Jozef (2003). Nanotechnology: A new frontier in food Science. Food Technology, 57: 24-29.

Naderi, M., A.A. Danesh Shahraki, and R. Naderi (2011). Application of nanotechnology in the optimization of formulation of chemical fertilizers. Iran. J. Nanotechnol. 12:16-23.

Nardi, S., Concheri, G. and G. Dell'agnola, 1996. Biological activity of humus. In: Humic substances in terrestrial. The Netherlands: Elsevier; pp. 361406

Snedecor, G. W and W. G. Cochran (1990).Statistical Methods. Oxford and J. B. H. Bub. Com. $6^{\text {th }}$ Edition. pp: 507.

Suppan, S. (2013). Nanomaterials in soil: Our future food chain? The Institute of Agriculture and Trade Policy, Minneapolis, MN.

Tantawy, A.S., Y. A. M. Salama, A.M.R. Abdel-Mawgoud and A.A. Ghoname (2014). Comparison of chelated calcium with nano calcium on alleviation of salinity negative effects on tomato plants. Mid. East J. Agric. Res., 3(4): 912-916. 


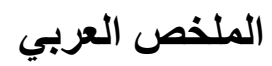 \\ جودة ومحصول عنب المائدة صنف "إيرلي سويت" المتأثرين بحامض الهيوميك}

ونانو كريونات الكالسيوم

محمود أحمد محمد علي'،حمد محمد محمد حرحش'، ثناء مصطفي عز '،عبد الحميد

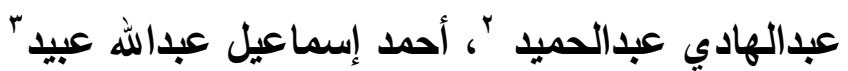

' قسم الإنتاج النباتي - كلية الزراعة سابا باشا - جامعة الأسكندرية.

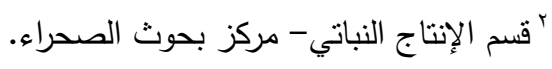

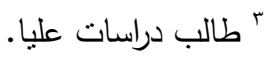

أجريت هذه الدراسة في مزرعة خاصة في الخطاطبة، محافظة المنوفية، مصر خلال الموسمين

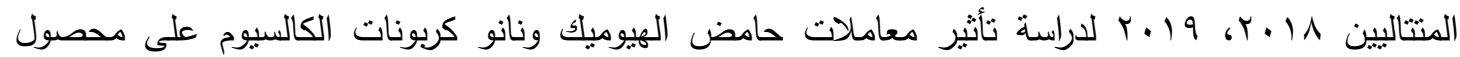

وجودة عنب المائدة صنف "إيرلي سويت" في تصميم عاملى قطاعات كاملة العشوائية بثلاث مكررات لكل

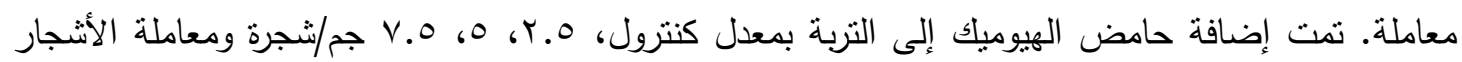
بنانو كربونات الكالسيوم (0. • \%) رش ورقى (كنترول، رش مرة واحدة بعد أسبوعين من العقد، رش مرتين بعد أسبوعين وأربع أسابيع من العقد). أوضحت النتائج أن إضافة حمض الهيوميك (بمعدله. ج. جم/شجرة) والرش بالنانو كربونات الكالسيوم

(مرنين بعد أسبوعين وأربع أسابيع من العقد) أعطت أعلي القيم لكل من وزن العنقود، عدد العناقيد/شجرة،

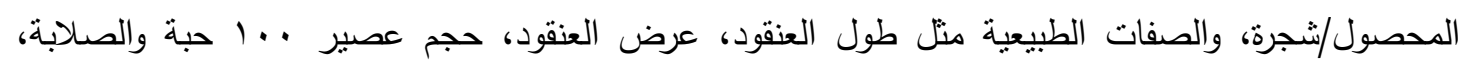
والمكونات الكيميائية متل \% للمواد الصلبة الذائبة الكلية، المواد الصلبة الذائبة الكلية/الحموضة، فيتامين سي، \% للكربوهيدرات مقارنة بمعاملة الكنترول التي سجلت أقل القيم لهذه الصفات خلال كلا الموسمين. 